\title{
Survey of Pyrenoid Distribution in Brown Algae*
}

\author{
by Terumitsu HORI**
}

Received January 25, 1971

\begin{abstract}
A study of pyrenoid distribution in field material of 52 species of brown algae was conducted with an electron microscope. Of the representatives examined, 17 species possessed pyrenoids, while the rest lacked pyrenoids.

It is interesting to note that most of the species possessing pyrenoids fall within the group of either isozamy or anisogamy, while those with lack pyrenoids fall within the group of oögamy.
\end{abstract}

Classification of the Phaeophyceae has been primarily based on the method of thallus formation and reproduction and the type of life histor $\mathrm{y}^{1-4)}$. According to Evans $^{5)}$, the first person who tried to introduce the distribution of pyrenoid in the taxonomy of the Phaeophyceae as a diagnostic character was Simon ${ }^{6)}$. However, her discussion was restricted to the results from light microscope observations. As far as I know, Evans ${ }^{5,7)}$ was the first to bring the results of electron microscope studies with pyrenoids in the taxonomy of the Phaeophyceae. He considered that distribution of pyrenoids was useful as an additional character in determining their taxonomic relationships. Recently, Cole and her co-workers have extensively carried out electron microscope studies of brown algae in relation to their phylogeny ${ }^{8-12}$. They were of the opinion that the following characters could be useful as criteria for their taxonomy as well as for their classification: the position of Golgi bodies, the presence or absence of pyrenoids, type of pyrenoid, arrangement of the plasmodesmata, cell wall structure, banding pattern of chloroplast thylakoids, presence or absence of chloroplast out-pocket and others ${ }^{9,10)}$.

The present study was undertaken for the purpose of providing an additional information as to the presence or absence of pyrenoids for field material of the Phaeophyceae. Studies on the fine structure of the various life history stages are now in progress, and the results will be presented in another paper.

\section{Materials and Methods}

The algae surveyed in the present study are listed in Table 1 with their species names and localities and dates of collection. The systematic arrangement presented in the list follows essentially that of Kylin ${ }^{1)}$.

The materials examined were all from vegetative portions of the specimens collected in nature.

* This work was supported, in part, by research grant from Japan Society for the Promotion of Science, and, in part, by Grant No. 4050 from the Ministry of Education of Japan. Contribution from the Shimoda Marine Biological Station, Tokyo University of Education, No. 201.

** Biological Institute, Faculty of Science, Toho University, Narashino, Chiba, Japan. 
Table 1. Details of representatives investigated.

\begin{tabular}{|c|c|c|c|}
\hline Species & Source & \multicolumn{2}{|c|}{ Collection } \\
\hline Giffordia indica & Nashiro, Okinawa. & Mar. & 1.969. \\
\hline Ectocarpus breviarticulatus & Nashiro, Okinawa. & Mar. & 1969. \\
\hline Botrytella micromora & Muroran, Hokkaido. & Jun. & 1969. \\
\hline Ralfsia verrucosa & Augoran, Hokkaido. & Aug. & 1968. \\
\hline Sphacelaria sp. & Nabeta, Izu. & Feb. & 1969. \\
\hline Sphacelaria sp. & Muroran, Hokkaido. & Aug. & 1968. \\
\hline Cutleria cylindrica & Shichirigahama, Kanagawa. & Feb. & 1968. \\
\hline Dictyota dichotoma & Hatsuse, Kanagawa. & Feb. & 1968. \\
\hline D. dilatata & Shichirigahama, Kanagawa. & Apr. & 1967. \\
\hline Padina arborescens & Nabeta, Izu. & Feb. & 1969. \\
\hline P. crassa & Zushi, Kanagawa. & Jun. & 1967. \\
\hline Dictyopteris undulata & Nabeta, Izu. & Mar. & 1968. \\
\hline D. divaricata & Muroran, Hokkaido. & May & 1968. \\
\hline D. prolifera & Shirahama, Izu. & May & 1967. \\
\hline Pachydictyon coriaceum & Shichirigahama, Kanagawa. & Mar. & 1968. \\
\hline Sphatoglossum pacificum & Shirahama, Izu. & May & 1967. \\
\hline Halothrix ambigua & Muroran, Hokkaido. & May & 1968. \\
\hline Petrospongium rugosum & Kominato, Chiba. & Jan. & 1969. \\
\hline Leathesia difformis & Muroran, Hokkaido. & May & 1968. \\
\hline Papenfussie!la kuromo & Hatsuse, Kanagawa. & Apr. & 1968. \\
\hline Heterochordaria abietina & Muroran, Hokkaido. & May & 1968. \\
\hline Scytosiphon lomentaria & Muroran, Hokkaido. & Mar. & 1967. \\
\hline Colpomenia sinuosa & Nabeta, Izu. & May & 1965. \\
\hline C. bullosa & Muroran, Hokkaido. & May & 1967. \\
\hline Petalonia fascia & Shichirigahama, Kanagawa. & Mar. & 1968. \\
\hline Hydroclathrus clathratus & Susaki, Izu. & Feb. & 1968. \\
\hline Coilodesme japonica & Muroran, Hokkaido. & Mar. & 1967. \\
\hline Myelophycus simplex & Chōjagasaki, Kanagawa. & Apr. & 1967. \\
\hline Ishige okamurai & Shichirigahama, Kanagawa. & Mar. & 1968. \\
\hline I. sinicola & Shichirigahama, Kanagawa: & Mar. & 1.968. \\
\hline Sporochnus scoparius & Shirahama, Izu. & May & 1.967. \\
\hline Desmarestia viridis & Muroran, Hokkaido. & Aug. & 1968. \\
\hline D. ligurata & Muroran, Hokkaido. & Aug. & 1.968. \\
\hline D. tabacoides & Susaki, Izu. & May & 1967. \\
\hline Laminaria japonica & Muroran, Hokkaido. & Aug. & 1968. \\
\hline L. religiosa & Muroran, Hokkaido. & Aug. & 1968. \\
\hline L. angustata & Muroran, Hokkaido. & Aug. & 1.968. \\
\hline Kjellaniella gyrata & Muroran, Hokkaido. & Aug. & 1968. \\
\hline Agarum cribrosum & Muroran, Hokkaido. & Aug. & 1968. \\
\hline Costaria costata & Muroran, Hokkaido. & Aug. & 1968. \\
\hline Eisenia bicyclis & Muroran, Hokkaido. & Aug. & 1968. \\
\hline Ecklonia cava & Susaki, Izu. & May & 1967. \\
\hline Eckloniopsis radicosa & Susaki, Izu. & May & 1.967. \\
\hline Undaria pinnatifida & Shichirigahama, Kanagawa. & Feb. & 1969. \\
\hline Alaria crassifolia & Muroran, Hokkaido. & May & 1968. \\
\hline Fucus evanescens & Muroran, Hokkaido. & May & 1.968. \\
\hline Sargassum thunbergii & Susaki, Izu. & May & 1967. \\
\hline S. nigrifolium & Susaki, Izu. & May & 1967. \\
\hline S. confusum & Muroran, Hokkaido. & May & 1968. \\
\hline S. sagamianum & Susaki, Izu. & May & 1967. \\
\hline S. ringgoldianum & Susaki, Izu. & May & 1967. \\
\hline Hizikia fusiforme & Nabeta, Izu. & Mar. & 1968. \\
\hline
\end{tabular}


Materials were fixed in glutaraldehyde at $4-6^{\circ}(3 \%$ or $6 \%$ in phosphate buffer $\mathrm{pH} 7.0$, or $6 \%$ in sea water) and post-fixed in $\mathrm{OsO}_{4}$ at $4-6^{\circ}(1 \%$ or $2 \%$ in phosphate buffer $\mathrm{pH} 7.0)$ or in unbuffered $\mathrm{KMnO}_{4}(2 \%)$ at room temparature. Part of each material was also fixed only in $\mathrm{OsO}_{4}(2 \%$ in phosphate buffer $\mathrm{pH} 7.0)$. After rinsed for 15 minutes with several changes of buffer, they were dehydrated in a graded series of ethyl alcohol and propylene oxide and were embedded in Epon $812^{133}$. Sections were cut with glass knives on a Porter-Blum microtome and stained in lead citrate $^{14)}$, and examined with a JEM-7 electron microscope.

\section{Observations}

Ectocarpales: Four representatives of this order were examined in the present study. The occurrence of pyrenoids was confirmed in the chloroplasts of three species of the Ectocarpus-complex; Ectocarpus breviarticulatus, Giffordia indica, and Botrytella micromora (Fig. 1): but no pyrenoid was detected in Ralfsia verrucosa* (Fig. 2). Regarding the Ectocarpus-complex, these results are in good agreement. with those of previous works by Gibbs ${ }^{15)}$, Giraud ${ }^{16)}$, Bouck ${ }^{17)}$, and Evans ${ }^{5)}$. Regarding the pyrenoid in Ralfsia, however, the present result is in contradiction to that of Loiseaux ${ }^{18)}$ who reported the presence of pyrenoids in Ralfsia clavata. Since the heterogeneity of this genus has been the subject of recent culture studies, this contradiction suggests the need for further investigation of the fine structure in connection with the life history.

Sphacelariales: Two species of Sphacelaria were examined in this study and no pyrenoid was detected in their chloroplasts. This result agrees with that of Simon ${ }^{6}$. However, according to Evans ${ }^{5)}$ the zoospores of $S$. bipinnata possess pyrenoids. Accordingly, his result also suggests the need for further observations on different stages in the life history of this genus.

Cutleriales: In Cutleria cylindrica, pyrenoids were detected only in a few chloroplasts of the cortical cells. These pyrenoids are all extremely small, measuring less than $1.0 \mu$ in length as well as in width. They seem to be very poorly developed (Fig. 3). They are always located at the edge of the chloroplasts, protruding into the cytoplasm. All of the vegetative cells except those of cortical portion seem to lack pyrenoids. According to previous works of Simon $^{6)}$ and Evans ${ }^{5)}$, however, no alga in this genus possessed pyrenoids. Detailed discussions are not possible at the present time because these authors mentioned neither the species names nor the portion of thallus they used.

Dictyotales: Nine representatives of this order were examined, but no evidence of the occurrence of pyrenoids was detected in their chloroplasts (Fig. 4). This result corresponds well to that of $\mathrm{Ueda}^{19)}$, Berkaloff ${ }^{20)}$ and Evans ${ }^{5)}$. In a recent paper, Liddle and Neushal ${ }^{21}$ reported the presence of pyrenoids in Zonaria farlowii in vegetative cells as well as in egg cells. However, it is rather strange to me that there is no structure corresponding to pyrenoid in their text photomicrographs.

* Identification of this alga was kindly made by Professor Y. Nakamura, Algological Research Institute, Faculty of Science, Hokkaido University, to whom I am indebted. 
Chordariales: Eight species of this order were examined in this study and pyrenoids were found in seven representatives (Figs. 5, 10, 12) (cf. Table 2). As far as I know, three species were previously studied with an electron microscope and all have been known to possess pyrenoids: Myrionema orbiculare by Loiseaux ${ }^{18)}$, Leathesia difformis by Cole and $\operatorname{Lin}^{10)}$ and Eudesme virescens by Cole ${ }^{11)}$.

In connection with the present results, a few comments should be mentioned regarding the systematic position of Heterochordaria abietina. As to this species, Nakamura ${ }^{22)}$ discussed its similarity to Ralfsia verrucosa, a species of Ralfsia sensu stricto, on the basis of the method of thallus formation and the type of life history. $\mathrm{He}$ is of the opinion that these two algae should be placed in the same taxon. As described above, my study confirmed that these two algae have no pyrenoids. This evidence seems to provide an additional criterion to Nakamura's classification.

In the present study I have not been able to find pyrenoids in the chloroplast of Ishige sinicola. The question arises at once whether it lacks pyrenoids completely or it may rarely possesses pyrenoids, since in a related alga, I. okamurai (Fig. 12), pyrenoids were very rarely recognized in this investigation. Further study to confirm it is now under way.

Punctariales: Six representative were examined (Table 1) and all of them possess pyrenoids (cf. Table 2). Their pyrenoids are fairly large, and hence they are easily recognized (Figs. 6-9).

Sporochnales and Desmarestiales: No pyrenoid was detected in such representatives of these orders as Sporochnus scoparius, Desmarestia tabacoides (Fig. 11), D. ligulata and $D$. viridis.

Laminariales: The following eight species of this order were examined-Kjellmaniella gyrata, Agarum cribrosum, Costaria costata, Eisenia bicyclis, Ecklonia cava, Eckloniopsis radicosa, Undaria pinnatifida (Fig. 13), and Alaria crassifolia. No pyrenoid could be identified in all of them except Undaria pinnatifida in which a few chloroplasts possess a small lateral bud-like body that protrudes into the cytoplasm (Fig. 13). At present, I cannot say definitely whether it is a sort of " rudimentary pyrenoid"7) or "out-pocket" "11). The results concerning other species agree with the findings of Evans $^{5)}$ and Simon ${ }^{6)}$.

Fucales: Seven species of three genera were investigated-Sargassum ringgoldianum (Fig. 15), S. nigrifolium (Fig. 16), S. thunbergii, S. confusum, S. sagamıanum, Hizikia fusiforme (Fig. 14), and Fucus evanescens, but no pyrenord was encountered. According to Evans ${ }^{7)}$, a vestigial pyrenoid was present in the egg chloroplasts of British fucoids, Bifurcaria bifurcata, Himanthalia elongata and Cystoserra tamariscifolia, but not in those of Ascophyllum nodosum, Fucus serratus, F. spiralis. Pelvetia canaliculata and Halidrys siliquosa, or in the vegetative cells of B. bifurcata and C. tamariscifolia.

\section{Discussion}

All species of brown algae that have been examined so far with an electron microscope are listed in Table 2, which includes about eighty species of fifty-one genera. From the results of the present study and the data available at the present 

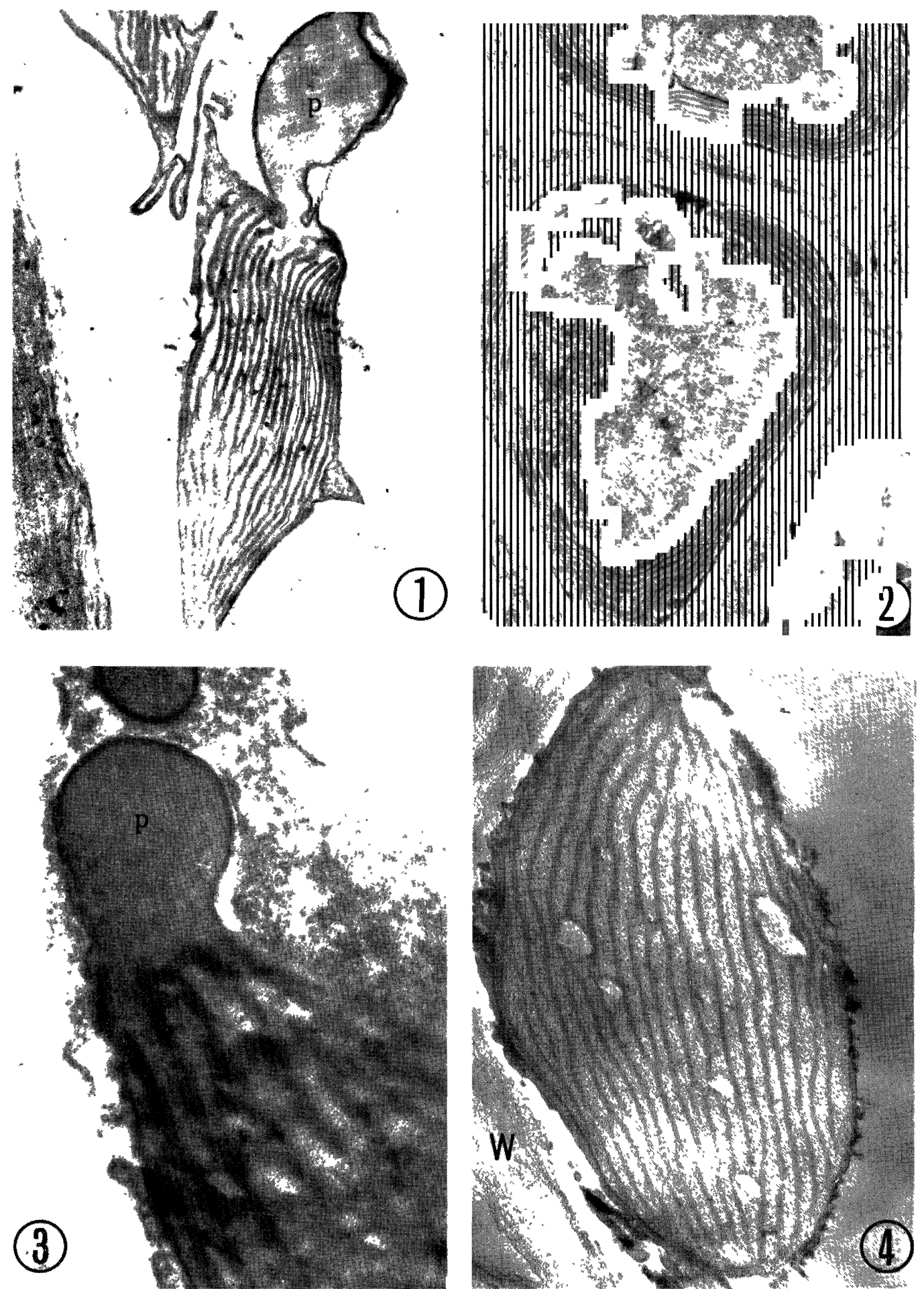

Fig. 1. Botryte!la micromora. A chloroplast with a pyrenoid. $(\times 9,800)$

F1g. 2. Ralfsia verrucosa. A chloroplast without a pyrenoid. $(\times 11,000)$.

Fig. 3. Cutleria cylindrica. A part of a chloroplast with a pyrenoid. $(\times 61,000)$.

Fig. 4. Pachydrctyon corraceum. A chloroplast showing the lack of a pyrenoid $(\times 23,000)$.

Key to abbreviations. $\mathrm{m}$ : mitochondria; $\mathrm{N}$ : nucleus; $\mathrm{p}$ : pyrenoid; $\mathrm{w}$ : cell wall. 

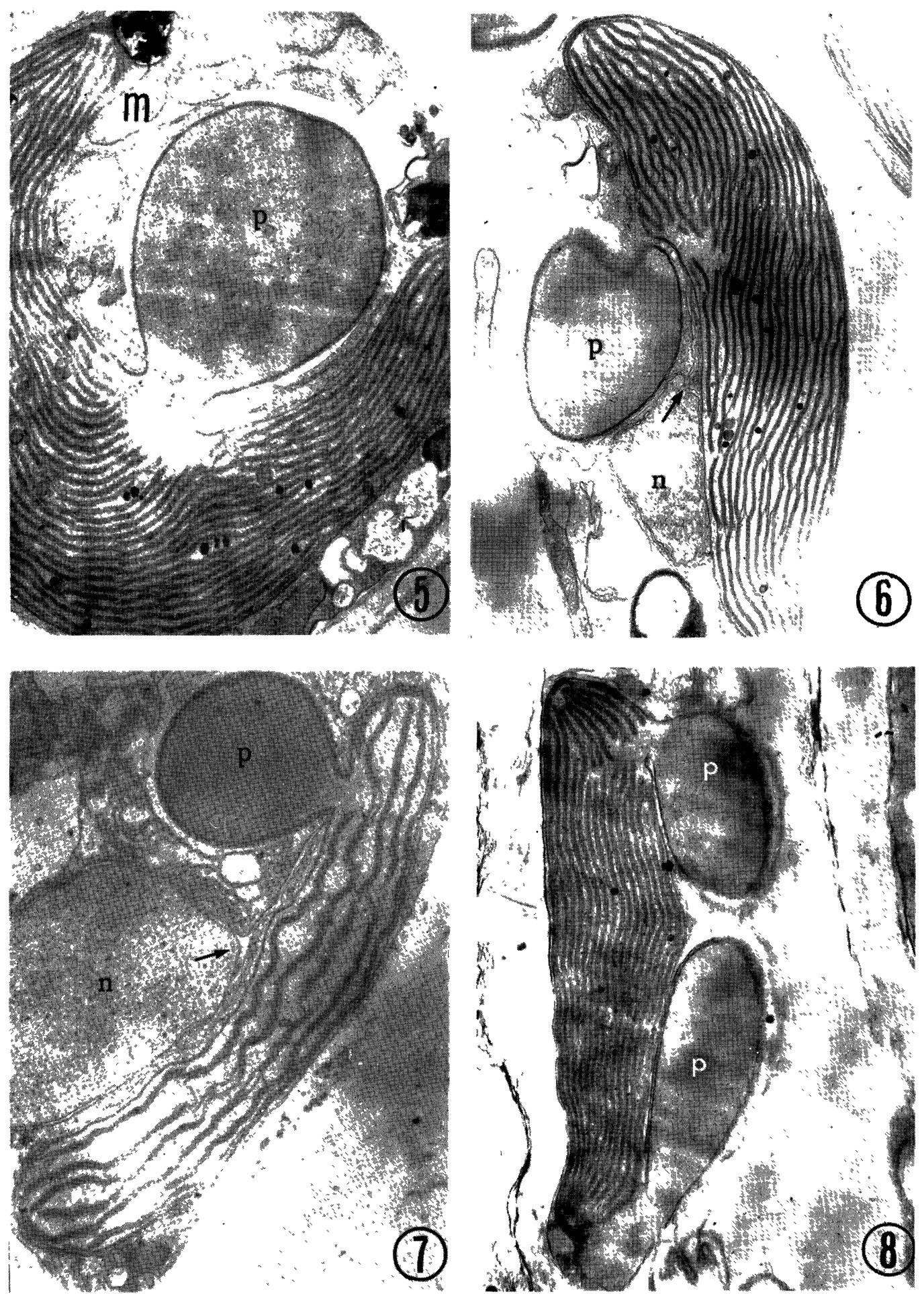

Fig. 5. Petrospongium rugosum. A chloroplast with a pyrenoid in thallus cell. $(\times 9,400)$.

Fig. 6. Scytosiphon lomentaria. A chloroplast and non-median section of pyrenoid. Tubule (arrow) extending from nucleus in visible. $(\times 11,900)$.

Fig. 7. Colpomenia bullosa. Section of a chloroplast with a pyrenoid. Also visible are a pair of membranes extending from the outer nuclear membrane (arrow). $(\times 16,000)$.

Fig. 8. Coilodesme japonica. A chloroplast with two stalked pyrenoids near both ends. $(\times 12,500)$. 

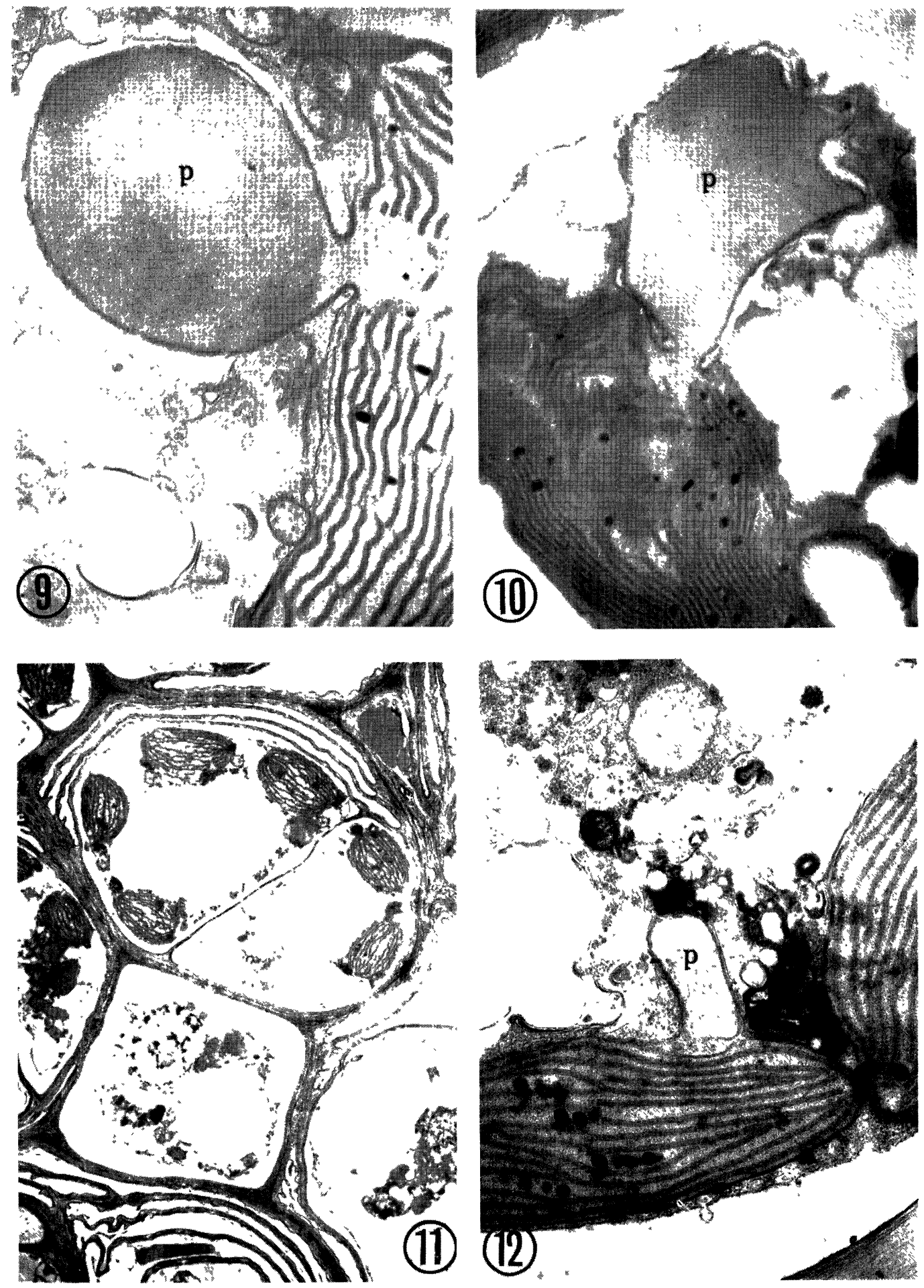

Fig. 9. Hydroclathrus 'clathratus. A chloroplast with a pyrenoid. $(\times 8,700)$.

Fig. 10. Myelophycus simplex. A part of a chloroplast with an unusual shape of pyrenoid. $(\times 16,300)$.

Fig. 11. Desmarestia tabacoides. Many chloroplasts without pyrenoids. A cell is enclosed about half way around by some separate thin layers of cell wall. $(\times 2,800)$.

Fig. 12. Ishige okamurai. A chloroplast bearing a small pyrenoid. $(\times 24,400)$. 

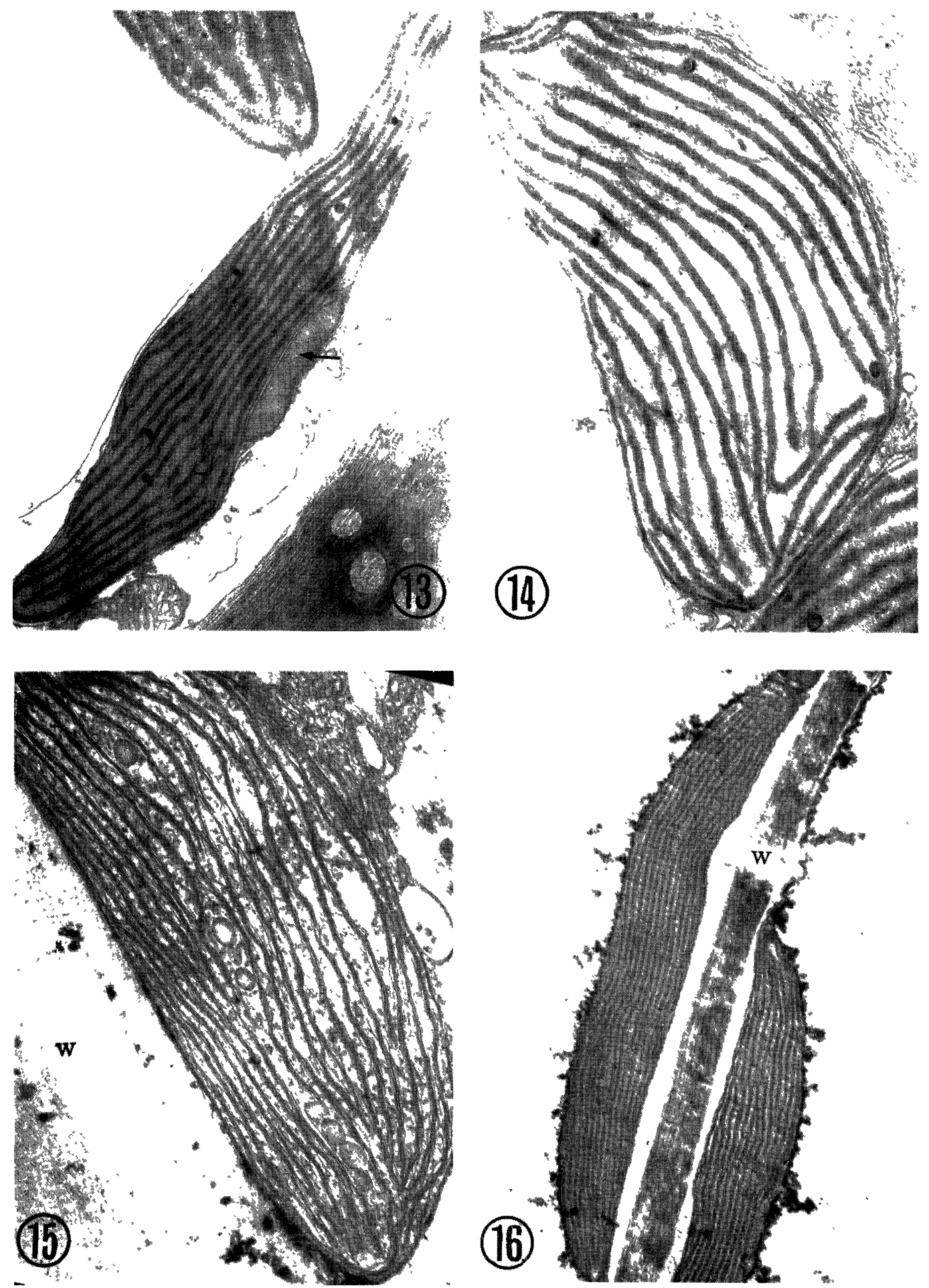

Fig. 13. Undaria pinnatifida. A chloroplast bearing the bud-like body resembling a rudimentary pyrenoid. $(\times 19,900)$.

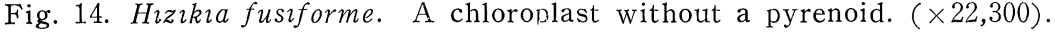

Fig. 15. Sargassum ringgoldianum. A chloroplast without a pyrenoid. $(\times 27,000)$.

Fig. 16, S. nigrifolium. Chloroplasts without a pyrenoid. $(\times 11,900)$. 
Table 2. List of brown algae investigated with an electron microscope.

\begin{tabular}{|c|c|c|c|}
\hline \multirow[b]{2}{*}{ Species } & \multicolumn{2}{|c|}{ Presence or absence of pyrenoid ${ }^{1}$} & \multirow[b]{2}{*}{ References } \\
\hline & in reproductive & $\begin{array}{l}\text { in vegetative } \\
\text { cells }^{2}\end{array}$ & \\
\hline \multicolumn{4}{|l|}{ Ectocarpales: } \\
\hline Ectocarpus breviarticulatus & & + & \\
\hline E. confervoides & $(+)$ & & 5. \\
\hline Giffordia indica & & + & \\
\hline Giffordia sp. & & $(+)$ & 17. \\
\hline Pilayella sp. & & & 16. \\
\hline Pilayella littoralis & $(+)$ & $(+)$ & 5,15 \\
\hline Botrytella micromora & & + & \\
\hline Ralfsia verrucosa & & - & \\
\hline R. clavata & & & 18. \\
\hline \multicolumn{4}{|l|}{ Sphacelariales : } \\
\hline Sphacelaria bipinnata & $(+)$ & & 5. \\
\hline Sphacelaria sp. & & - & \\
\hline Sphacelaria sp. & & - & \\
\hline \multicolumn{4}{|l|}{ Cutleriales: } \\
\hline unknown species ${ }^{3}$ & & & 5. \\
\hline Cutleria cylindrica & & + & \\
\hline \multicolumn{4}{|l|}{ Dictyotales: } \\
\hline Dictyopteris membranacea & & & 5. \\
\hline D. divaricata & & - & \\
\hline D. prolifera & & - & \\
\hline D. undulata & & - & \\
\hline Dictyota dichotoma & $(-)$ & $(-),-$ & $5,23$. \\
\hline D. dilatata & & - & \\
\hline Pachydictyon coriaceum & & - & \\
\hline Padina arborescens & & - & 19. \\
\hline P. crassa & & - & \\
\hline P. pavonia & & $(-)$ & 5. \\
\hline Sphatoglosum pacificum & & - & \\
\hline \multicolumn{4}{|l|}{ Chordariales: } \\
\hline Halothrix ambigua & & + & \\
\hline Leathesia difformis & & $(+),+$ & 10. \\
\hline Petrospongium rugosum & & + & \\
\hline Papenfussiella kuromo & & + & \\
\hline Heterochordaria abietina & & - & \\
\hline Myelophycus simplex & & + & \\
\hline Ishige okamurai & & + & \\
\hline I. sinicola & & - & \\
\hline Myrionema orbiculare & & & 18. \\
\hline Eudesme virescens & & $(+)$ & 11. \\
\hline
\end{tabular}


Punctariales:

Colpomenia bullosa

C. peregrina

C. sinuosa

Hydroclathrus clathratus

Petalonia fascia

Phaeostrophion irregulare Scytosiphon lomentaria Coilodesme japonica

Dictyosiphonales:

Dictyosiphon foeniculaceus Sporochnales :

unknown species ${ }^{3}$

Sporochnus scoparius

Desmarestiales :

Desmarestia ligulata

D. viridis

D. tabacoides

Laminariales :

Chorda filum

Agarum cribrosum

Costaria costata

Kjellmaniella gyrata

Laminaria angustata

L. digitata

L. japonica

L. religiosa

Saccorhiza polyschides

Alaria crassifolia

A. esculenta

Ecklonia cava

Eckloniopsis radicosa

Egregia menziesii

Eisenia bicyclis

Undaria pinnatifida

Fucales:

Ascophyllum nodosum

Fucus evanescens

$F$. serratus

F. spiralis

F. vesiculosus ${ }^{6}$

Pelvetia canaliculata

Himanthalia elongata

H. lorea

Bifurcaria bifurcata

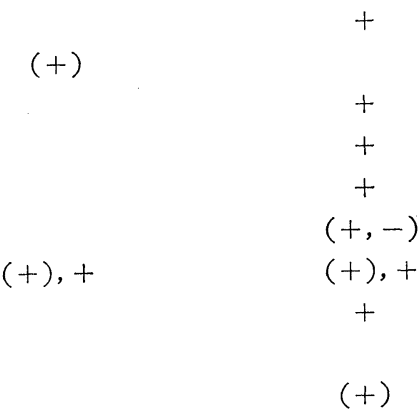

5.

9.

5,25 .

5.

5.

5,17 .

5.

5.

5.

24.

8.

8.

8.

$17,26$.

8.

8.

20.

8.

(continued) 


Cystoseira tamariscifolia
Halidrys siliquosa
Sargassum confusum
S. nigrifolium
S. ringgoldianum
S. sagamianum
S. thunbergii
Hizikia fusiforme

$(+)$

$(-)$

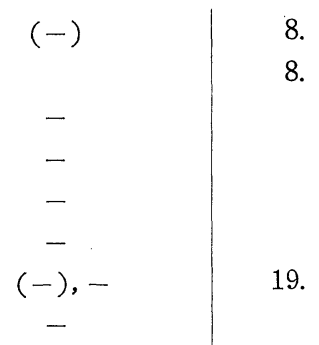

1 In this table a mark of plus shows the presence of pyrenoids, and a mark of minus indicates that the pyrenoid has not yet been observed.

2 In this rank, egg, zoospore and settled spore were involved.

3 In original the species name was not described.

4 Parentheses in two ranks, e.g., reproductive and vegetative cells, indicate the results being studied by previous observers, but when placed in the middle they indicate that the part of thallus was not mentioned.

5 This alga was described as a member of the Dictyosiphonales in original ${ }^{9}$.

6 This alga has been observed by many electron microscopists.

time, the following conclusions may be drawn.

First, it is interesting to note that great majority of algae which contain pyrenoids are the members belonging to more primitive taxa. These members are of the algae of either isogamy or anisogamy in the method of their reproduction. However, there are a few exceptions such as Ralfsia verrucosa (Ectocarpales), Heterochordaria abietina (Chordariales), and possibly Ishige sinicola (Chordariales).

Second, the members of the Dictyotales, Laminariales, Sporochnales, and Desmarestiales lack pyrenoids. It should be noted that these members are all of the algae of oögamy in the method of reproduction.

Third problem concerns the pyrenoids of Cutleria cylindrica. To judge from the photographs given by Evans ${ }^{7)}$ of the rudimentary type of pyrenoid in fucalean egg chloroplasts, such a pyrenoid seems to fall within the range from 0.5 to $1.0 \mu$ in size, in width as well as in length. The pyrenoid of $C$. cylindrica is also very small and measures about $0.5 \mu$ in width and about $0.9 \mu$ in length, a size well in correspondence with the so-called rudimentary pyrenoid of Evans. The usual type of pyrenoid in most of brown algae is in the range from 1.5 to $3.0 \mu$ in width and from 1.5 to $2.5 \mu$ in length (Hori, unpublished data). These evidences appear to suggest that there is a gradation in characteristics from algae bearing a usual type of pyrenoid and having either isogamous or anisogamous reproduction, through algae with a rudimentary type of pyrenoid and with either anisogamous or oögamous reproduction, to those bearing no pyrenoid and having oögamous reproduction. If we accept this hypothesis, the present study could support the view of $\mathrm{Kylin}^{1)}$ that the Cutleriales in a taxon to be placed systematically between the Ectocarpales and the Tilopteridales-Dictyotales.

Fourth, as discussed briefly in the preceeding pages, in some cases pyrenoid distribution is not in agreement with each other between vegetative cells and reproductive ones even in identical species or the closely related taxa. As far as the present study is concerned, species of Sphacelaria and those of the Fucales show such an example. As has been emphasized by Cole and her co-workers ${ }^{9,11}$, it should surely be important to study fine structures of algae in various stages of 
their life history.

I wish to thank Professor K. Hayashi and members of his staff, and Asst. Professor R. Ueda in the Department of Botany, Faculty of Science, Tokyo University of Education for their support during the course of this work, and also Professor Y. Nakamura and his co-workers in the Institute of Algological Research, Faculty of Science, Hokkaido University for their helpful advice and preparation of materials, and Dr. M. Chihara, in National Science Museum, Ueno, Tokyo, for helpful advice and discussion. I wish to express my thanks to Mrs. M. Yoshizaki and Y. Hara for providing with some of materials studied in the present work.

\section{Addendum}

After the present manuscript was completed, one paper by Dr. Cole on the ultrastructural study of three species in the order Scytosiphonales appeared in Phycologia, volume $9(3 / 4), 1970$. According to her paper, the presence of pyrenoids was detected in the chloroplasts of field material of Colpomenia sinuosa, Petalonia debilis and Scytosiphon lomentaria, and of sporeling of Petalonia. Her findings regarding the field material are in accord with mine.

\section{References}

1) Kylin, H., Lunds Univ. Årasskr., N. F., 29 : 1-1.02 (1.933).

2) Fritsch, F.E., The structure and reproduction of the algae. II. Cambridge University Press, p. 939 (1945).

3) Papenfuss, G. F., In Smith, G. M. (ed.), Manual of Phycology. Waltham, Mass. Chronica Botanica, p. 119-158 (1951.).

4) Smith, G. M., Cryptogamic Botany I. Algae and fungi. McGraw-Hill, New York, p. 546 (1955).

5) Evans, L. V., J. Cell Science 1: 449 (1.966).

6) Simon, M.F., Rev. Cytol. Biol. vég. 15: 73 (1.954).

7) Evans, L. V., New Phytol. $67: 173$ (1968).

8) Cole, K., Bourne, V. and Lin, S-C., Can. J. Genet. Cyto1. 10: 63 (1968).

9) Bourne, V.L. and Cole, K., Can. J. Bot. $46: 1369$ (1968).

10) Cole, K. and Lin, S-C., Syesis, 1: 103 (1968).

11) Cole, K., Phycologia 8: 101 (1969).

12) Cole, K. and Lin, S-C., Can. J. Bot. 48 :
$265(1.970)$

13) Luft, J.H., J. Biophys. Biochem. Cytol. 9: 409 (1961).

14) Reynolds, S., J. Cell Biol. $17: 208$ (1963).

15) Gibbs, S. P., J. Ultrastr. Res. $7: 247$ (1962).

16) Giraud, G., J. Microscopie 1:251 (1962).

17) Bouck, G. B., J. Cell Biol. $26: 523$ (1965).

18) Loiseaux, S., Rev. Gen. Bot. $74: 329$ (1967).

19) Ueda, K., Cytologia $26: 344$ (1.961).

20) Berkaloff, C., J. Microscopie 2 : 213 (1.963).

21) Liddle, L. B. and Neushul, M., J. Phycol. 5: 4 (1969).

22) Nakamura, Y., Abstract of Proc. 28th Ann. Meet. Bot. Soc. Japan. Okayama, p. 42-43 (in Japanese) (1963).

23) Berkaloff, C., J. Microscopie $1: 313$ (1962).

24) Bisalputra, T. and Bisalputra, A. A., J. Cell Biol. 33 : 511 (1967).

25) Greenwood, A.D., In The plastid (ed. Kirk, J. T. O. and Tilney-Bassett, R. A.E.). W. H. Freeman and Co., San Francisco, p. 608 (1.967).

26) McCully, M. F., J. Cell Science $3: 1$ (1968). 